\title{
Immunogens Consisting of Oligosaccharides from the Capsule of Haemophilus influenzae Type b Coupled to Diphtheria Toxoid or the Toxin Protein CRM197
}

\author{
Porter Anderson, Michael E. Pichichero, and Richard A. Insel \\ Department of Pediatrics, University of Rochester Medical Center, Rochester, New York 14642
}

\begin{abstract}
Haemophilus influenzae type b (Hib) capsular polysaccharide (PRP) was selectively hydrolyzed to reducing oligosaccharides, and the fraction containing 3-10 ribosylribitolphosphate repeating units (VS) was conjugated by reductive amination to diphtheria toxin (DTx), its nontoxic derivative CRM197 (Dcr), or diphtheria toxoid (DTd). Conjugate DTx-VS retained $\sim 1 \%$ of native toxicity, which was eliminated by treatment with formalin. Immunization of rabbits with the conjugates elicited antibody (Ab) to PRP and to DTx but not to a model for the linkage determinant.

Human adults given single subcutaneous injections had rises in serum Ab to PRP and in bactericidal activity in vitro; the Ab protected infant rats challenged with Hib. Adults had rises also in Ab to DTd, and these Ab protected rabbits against DTx.

A series of two injections of the conjugates Der-VS and DTd-VS was tested in infants beginning at 19-23 mo of age. Rises in anti-PRP Ab after the primary resembled the rises after PRP vaccine. In contrast to $P R P$, the conjugates elicited large rises after the secondary vaccinations and a substantial IgG component. Development of bactericidal activity paralleled the rises in anti-PRP Ab. Secondary rises after Dcr-VS were higher than after DTd-VS. In infants 12-16 mo of age, DcrVS (but not DTd-VS) elicited strong primary and secondary Ab responses that included IgG and bactericidal activity. Both conjugates produced consistent rises in Ab to DTd.
\end{abstract}

\section{Introduction}

Serum antibodies $(\mathrm{Ab})^{1}$ to the capsular polysaccharide can protect against invasion by Haemophilus influenzae type $b$ (Hib). Vaccination with the capsular polysaccharide of Hib (PRP) appears to induce a response adequate for protection above the age of $\sim 18 \mathrm{mo}$ (1). Since the maximal age incidence of Hib meningitis is $\sim 9$ mo (1), several laboratories have tried to increase the immunogenicity of PRP in infancy. A recent

Received for publication 29 August 1984 and in revised form 7 March 1985.

1. Abbreviations used in this paper: $\mathrm{Ab}$, antibody; $\mathrm{AU}$, antitoxinneutralizing units; BC, bactericidal; Dcr, cross-reacting material 197 (CRM197); DTd, diphtheria toxoid; DTx, diphtheria toxin; ELISA, enzyme-linked immunosorbent assay; Hib, Haemophilus influenzae type b; PAGE, polyacrylamide gel electrophoresis; Pi, inorganic phosphate; PRP, Haemophilus influenzae type b capsular polysaccharide; Td, adult-type tetanus-diphtheria toxoid vaccine; USFDA, U. S. Food and Drug Administration.

J. Clin. Itvest.

(C) The American Society for Clinical Investigation, Inc. 0021-9738/85/07/0052/08 $\$ 1.00$

Volume 76 , July $1985,52-59$ approach to the problem has used an old principle, the covalent coupling of polysaccharides or related oligosaccharides to a carrier protein (2). The former (coupling of intact PRP) is being examined by Chu and colleagues (3). To examine the latter possibility (4) we conjugated oligosaccharides of PRP to cross-reacting material 197 (CRM197) (Dcr) (5), a nontoxic derivative of diphtheria toxin (DTx); in weanling rabbits the conjugates induced high titers of anti-PRP Ab in an anamnestic pattern, and the $\mathrm{Ab}$ were bactericidal $(\mathrm{BC})$ to $\mathrm{Hib}$ in vitro (4).

Here, such conjugates were studied in humans. In addition to Dcr, native DTx and formalinized diphtheria toxoid (DTd) were tried as carriers. Adults were injected to examine for adverse reactions, for immunogenicity of the $\mathrm{Hib}$ and diphtheria components, and for the protective potential of the $\mathrm{Ab}$ elicited. Infants 19-23 and 12-16 mo of age were tested, and secondary injections were given to look for an anamnestic response.

\section{Methods}

Purified DTx (lot 1) and DTd (lot Dcp 27) were obtained from W. Latham of the Massachusetts Department of Public Health Biolabs, Jamaica Plain, MA. Der was isolated by $\left(\mathrm{NH}_{4}\right)_{2} \mathrm{SO}_{4}$ fractionation and chromatography as described (5) from Corynebacterium diphtheriae C7 (B197) furnished by J. R. Murphy, Boston University. Bovine serum albumin (BSA) was Cohn Fraction V from Sigma Chemical Co., St. Louis, MO. Protein was assayed by the method of Lowry et al. (6) with BSA as the standard. Electrophoresis in polyacrylamide gels containing sodium dodecyl sulfate (SDS-PAGE) was as described by Laemmli (7) (Fig. 1). The DTx and Dcr preparations, as expected, appeared as three discrete bands: the 62,000 -mol-wt native molecule and the A and B fragments $(24,000$ and $38,000 \mathrm{~mol} \mathrm{wt}$, respectively) produced by reduction of "nicked" molecules (5). The DTd preparation appeared mainly as a diffuse band with a molecular weight of 60 70,000 , with a small proportion of higher molecular weight material (presumably protein cross-linked by formalin [8]).

PRP in sodium salt form was isolated from Hib strain Eag as described (9). PRP is a linear polymer of the repeating structure (3- $\beta$ D-ribose [1-1] ribitol-5-phosphate-). Cleavage of the 1-1 bond produces one reducing ribosyl and one nonreducing ribitol terminus; the other two possible cleavages produce a phosphate monoester. For oligosaccharides with a high proportion of reducing termini, $120 \mathrm{mg}$ PRP in $12 \mathrm{ml}$ water at $0^{\circ} \mathrm{C}$ was made $0.1 \mathrm{~N}$ with $\mathrm{HCl}$, heated 4 min at $100^{\circ} \mathrm{C}$, cooled, neutralized with triethylamine, and applied to and eluted from a $1.5 \times 98-\mathrm{cm}$ column of Bio-Gel P-10 (Bio-Rad Laboratories, Richmond, CA) equilibrated with sterile $0.01 \mathrm{M}$ triethyl ammonium acetate. The fractions with elution coefficients of 0.4-0.9 were combined, designated "VS," and characterized as follows: total ribose content was assayed by the orcinol reaction (10) with D-ribose as standard. Content of ribose at reducing termini was estimated by the Park-Johnson assay for reducing sugars (10), also with D-ribose as standard. Content of phosphate monoester termini was estimated by measuring the inorganic phosphate $(\mathrm{Pi})$ released by potato acid phosphatase (Sigma Chemical Co.) as follows: samples in $0.1 \mathrm{M}$ sodium acetate buffer, $\mathrm{pH} 5$, were incubated overnight at $24-26^{\circ} \mathrm{C}$ with or without the enzyme present at $0.1 \mathrm{mg} / \mathrm{ml}$; Pi was measured by the method of Chen et al. (11); Dribose-5-phosphate was used as a control in this assay and found to be 97\% converted to $\mathrm{Pi}$. In preparation VS the ratio of reducing ends to 


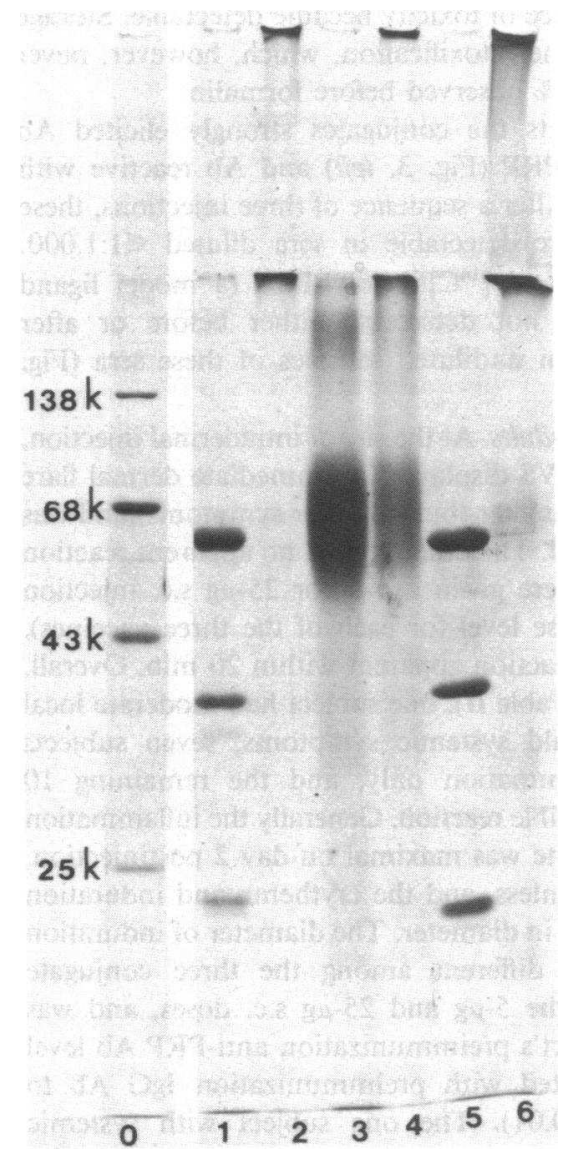

Figure 1. Analysis of carrier proteins and the corresponding conjugate antigens by SDS-PAGE. The discontinuous gel/buffer system of Laemmli (7) was used. The stacking (upper) layer contained $4 \%$ and the separating layer contained $10 \%$ polyacrylamide. Before application to the gel the samples (10 $\mu \mathrm{g}$ protein each) were heated to $100^{\circ} \mathrm{C}$ in cracking buffer containing 3\% 2-mercaptoethanol (vol/vol). The sample lanes contained the following: 1, Dcr, 2, conjugated DcrVS; 3, DTd; 4, conjugate DTd-VS; 5, DTx; and 6, conjugate DTxVS. Lane 0 contained protein standards for molecular weight: $138,000 \mathrm{~mol} \mathrm{wt}$, beta galactosidase; 68,000 , BSA; 43,000 , ovalbumin; and 25,000 , chymotrypsinogen. Staining was with Coomassie Blue.

pentose was 0.063 and of monophosphate ends to pentose was 0.049 . Thus, the average chain length was $1 /(0.063+0.049)=8.9$ repeating units. About $56 \%$ of the oligosaccharides contained ribose at the reducing termini and are thus capable of coupling to primary amino groups by reductive amination (12); correspondingly, $\sim 56 \%$ of the nonreducing termini (the free terminus after conjugation) would be ribitol. The size distribution of the reducing saccharides on Bio-Gel P10 is shown in Fig. 2. Conjugation of VS to the three diphtheria proteins was carried out by reductive amination (12), using $0.2 \mathrm{M}$ potassium phosphate buffer, $\mathrm{pH} \mathrm{8}$, sodium cyanoborohydride at 20 $\mathrm{mg} / \mathrm{ml}$, and $20 \mu \mathrm{mol}$ (reducing activity) of VS and $30 \mathrm{mg}$ protein for DTx-VS and DTd-VS or $6.7 \mathrm{~mol}$ VS and $10 \mathrm{mg}$ protein for Dcr-VS. After $14 \mathrm{~d}$ of reaction at $37^{\circ} \mathrm{C}$ the protein fractions were isolated by precipitation with $\left(\mathrm{NH}_{4}\right)_{2} \mathrm{SO}_{4}$ in the presence of urea as described (4); these fractions were called conjugates even though they may have contained some unconjugated protein. Small samples were retained for assay of toxicity, and the remainder was treated with formalin in the presence of lysine as describe (8) to stabilize and/or detoxify the proteins. Concentrations or dosages refer to the protein content. For vaccines, the conjugates in isotonic, sodium phosphate-buffered saline, pH 7.4, were filter-sterilized, reassayed for protein and ribose, supplemented with $0.01 \%$ thimerosal (wt/vol), aseptically vialed, and tested

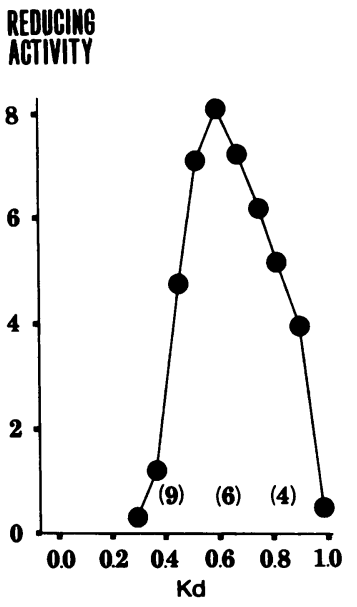

Figure 2. Bio-Gel P-10 elution profile of the reducing saccharides within oligosaccharide preparation VS. A sample containing $0.25 \mu \mathrm{mol}$ reducing activity was applied to a $0.8 \times 40$-cm column of the gel equilibrated with $0.01 \mathrm{M}$ triethylammonium acetate. The reducing sugar activity of the eluted fractions was determined by colorimetric assay (10) with D-ribose as the standard and is plotted on an arbitrary relative scale (filled circles). The numbers in parentheses above the horizontal axis denote the estimated chain length in ribosylribitolphosphate repeating units. $\mathrm{Kd}$, elution coefficient.

for sterility, general safety, and identity as specified by the U. S. Food and Drug Administration (USFDA) (13); they were also tested for endotoxin by the Limulus assay $(14,15)$ and found negative at a sensitivity of $0.1 \mathrm{ng} / \mu \mathrm{g}$ protein. PRP for use as a control vaccine was processed similarly. DTx activity was titrated in rabbit skin (16) with standardization by horse anti-DTx (Merrill Laboratories, Swiftwater, PA). Weanling rabbits were immunized with conjugates by three weekly subcutaneous injections of $25 \mu \mathrm{g}$ mixed with $\mathrm{AlPO}_{4}$.

1-D- $\left[{ }^{14} \mathrm{C}\right]$ Ribose $(0.05 \mathrm{mCi} / \mathrm{mmol}$; New England Nuclear, Boston, MA) was coupled to BSA by reductive amination to form $\left[{ }^{14} \mathrm{C}\right]$ ribitolylBSA as follows: $8 \mu \mathrm{Ci}$ of the ribose was reacted with $0.12 \mathrm{mg}$ BSA (12); after $2 \mathrm{~d}$ incubation at $37^{\circ} \mathrm{C}$ the protein was isolated as the void volume fraction on a Biogel P10 column and found to contain 28.6 $\mu \mathrm{Ci} / \mu \mathrm{mol}$ protein. This conjugate should lack antigenic identity with either PRP or DTx; but its linkage area should be identical to that in the VS conjugates (-CHOH-CH2-NH-) (12).

Adult human volunteers (age 22-43 yr) were healthy and had no history of serious allergy, of prior immunization with Hib antigen, or of immunization with DTd within 2 yr. They were bled for a preimmunization serum sample and tested for immediate hypersensitivity to conjugate (or thimerosal) by an intradermal injection of 0.5 $\mu \mathrm{g}$ of one of the conjugate vaccines. After $20 \mathrm{~min}$, subjects with no indication of hypersensitivity were given a single subcutaneous injection of $5 \mu \mathrm{g}$ or $25 \mu \mathrm{g}$ of the same vaccine. They were observed for $20 \mathrm{~min}$, then dismissed with instructions for self-assessment of adverse symptoms. Two similar control groups were given a single subcutaneous injection of either $1 \mu \mathrm{g}$ of PRP vaccine or adult type tetanus-diphtheria toxoid (Td) vaccine.

Infant subjects were healthy and had had no prior immunization with Hib vaccine nor history of serious adverse reaction to vaccines. The first group began the study at age 19-23 mo and at least one month after routine vaccination with diphtheria-tetanus-pertussis vaccine. They were bled, given a $25-\mu \mathrm{g}$ subcutaneous injection of Dcr-VS, DTd-VS, or PRP vaccine, observed at least $20 \mathrm{~min}$, and released to their parents for observation and recording of possible local and systemic adverse reactions. About 1 mo later this process was repeated with the same vaccine. About 1 mo and $\sim 4$ mo later they were again bled. A second group began the study at age 12-16 mo; thus the secondary Hib vaccination came at least 1 mo before the scheduled routine diphtheria-tetanus-pertussis booster at age $18 \mathrm{mo}$. Subjects received either Dcr-VS or DTd-VS as described for the 19-23-mo-old group; control data were taken from a previous study in a similar population (17).

Total Ab to PRP was measured in a Farr-type radioassay using $\left.{ }^{3} \mathrm{H}\right]$ PRP (18) and calibrated with standard antiserum SK (Office of Biologics, USFDA); $A b$ to the $\left[{ }^{14} \mathrm{C}\right]$ ribitolyl-BSA preparation was assayed similarly: $25 \mu \mathrm{l}$ of undiluted serum was reacted with $2 \mathrm{nCi}$ of the ${ }^{14} \mathrm{C}$ preparation. $\mathrm{BC}$ Ab to Hib was assayed with Hib strain Eag, 
and $\mathrm{Ab}$ passively protective against bacteremia was assayed in infant rats challenged intraperitoneally with $2 \times 10^{3}$ strain Eag (19). IgM, G, or A Ab to PRP was assayed in a microadaptation (4) of the EngvallPerlman enzyme-linked immunosorbent assay (ELISA).

IgG Ab to DTd was assayed by ELISA and calibrated with a preparation of human IgG containing a known antitoxin concentration. DTd antigenic equivalence of conjugates was estimated by inhibition in this assay calibrated with DTd. For ELISA, alkaline phosphatase (Sigma Chemical Co.) was coupled to affinity-purified goat Ab to rabbit or human immunoglobulins (Tago, Inc., Burlingame, CA). Neutralizing $\mathrm{Ab}$ to DTx was measured by inhibition in the rabbit skin assay mentioned above; in brief, dilutions of serum were preincubated with DTx at $0.005 \mathrm{U} / \mathrm{ml}$ and injected intradermally; after $5 \mathrm{~d}$ the site was examined for erythema.

The statistical methods were as described in (20). Estimates of variance, confidence intervals, and $t$ tests on the $A b$ values were performed on the logarithms of the values. Within sequential sera of a subject, a significant rise $(P<0.05)$ was computed to be $>30 \%$ in the radioassay and $>50 \%$ in ELISA.

\section{Results}

Preclinical characterization of the conjugates. The extent of coupling to the three carriers was similar and amounted to 510 ribosylribitolphosphate repeat units per protein molecule. Thus, $25 \mu \mathrm{g}$ of conjugate protein (the largest vaccine dose) would contain $\sim 1 \mu \mathrm{g}$ of oligosaccharide. The attached oligosaccharides were reactive in similar degree with $A b$ to native PRP, as indicated by inhibition of the radioassay using the standard human anti-PRP serum (Table I). At $>50 \mu \mathrm{g} / \mathrm{ml}$ the inhibition was $>95 \%$, indicating that the conjugates expressed all the antigenic determinants recognized in PRP by the standard serum. Reactivity with Ab to DTd ranged from $10 \%$ with Dcr-VS to $>100 \%$ with DTd-VS (Table I). In SDS-PAGE, conjugates DTx-VS and Dcr-VS appeared entirely as high molecular weight aggregates unable to penetrate the $4 \%$ stacking gel or the $10 \%$ separating gel; conjugate DTd-VS (like the original DTd) contained a broad band with a molecular weight of $60,000-70,000$ but contained more aggregates than DTd (Fig. 1). Dcr-VS and DTd-VS, like the original proteins, had no detectable DTx activity $(<0.00005 \mathrm{U} / \mu \mathrm{g}$ protein) as assayed in rabbit skin. DTx-VS after the conjugation reaction retained $\sim 1 \%$ of the toxicity of the original DTx. After formalin treatment the toxicity was $<0.01 \%$ of the original. Upon 4 mo

Table I. Composition and Antigenicity of the Conjugate Antigens

\begin{tabular}{|c|c|c|c|c|}
\hline \multirow[b]{2}{*}{$\begin{array}{l}\text { Conjugate } \\
\text { antigen }\end{array}$} & \multicolumn{2}{|c|}{$\begin{array}{l}\text { Content, mole per mole } \\
\text { of protein* }\end{array}$} & \multirow[b]{2}{*}{$\begin{array}{l}\text { Antigenic } \\
\text { equivalence§ }\end{array}$} & \multirow[b]{2}{*}{$\begin{array}{l}\text { Antigenic } \\
\text { equivalence§ }\end{array}$} \\
\hline & Pentơseł & $\begin{array}{l}\text { Organic } \\
\text { phosphate }\end{array}$ & & \\
\hline & & & $\begin{array}{l}\text { ng PRP/ } \\
\mu g \text { protein }\end{array}$ & $\begin{array}{l}\mu g D T d / \\
\mu g \text { protein }\end{array}$ \\
\hline DTx-VS & 6.7 & 7.3 & 0.5 & 0.7 \\
\hline Dcr-VS & 4.1 & 5.0 & 1.4 & 0.1 \\
\hline DTd-VS & 9.6 & 9.8 & 2.2 & 2.1 \\
\hline
\end{tabular}

* Based upon a molecular weight of 62,000 for the protein. $¥$ Assayed by the orcinol method (the ribosyl residue that couples to protein would not be detectable).

$\S$ Based upon inhibition of binding of the respective unconjugated antigens to antibody in ELISA. of storage at $4^{\circ} \mathrm{C}$ a trace of toxicity became detectable. Storage at $37^{\circ} \mathrm{C}$ accelerated the retoxification, which, however, never increased above the $1 \%$ observed before formalin.

In weanling rabbits the conjugates strongly elicited $\mathrm{Ab}$ reactive with native PRP (Fig. 3, left) and $A b$ reactive with DTd (Fig. 3, center). After a sequence of three injections, these two $\mathrm{Ab}$ activities were detectable in sera diluted $₹ 1: 1,000$. However, the binding of $\left[{ }^{14} \mathrm{C}\right]$ ribitolyl-BSA (a model ligand for the linkage) was not detectable either before or after immunization, even in undiluted samples of these sera (Fig. 3, right).

Studies in human adults. At the site of intradermal injection, one recipient of DTd-VS displayed an immediate dermal flare reaction of $20 \mathrm{~mm}$ diameter (but no other symptoms) and was not further immunized. The other 18 had no apparent reaction within $20 \mathrm{~min}$ and were given a $5-\mu \mathrm{g}$ or $25-\mu \mathrm{g} \mathrm{s.c.} \mathrm{injection}$ (three subjects per dose level for each of the three vaccines). None had any local reaction apparent within $20 \mathrm{~min}$. Overall, in the following $3 \mathrm{~d}$ (Table II), one subject had moderate local inflammation and mild systemic symptoms, seven subjects had mild local inflammation only, and the remaining 10 subjects had no discernible reaction. Generally the inflammation at the subcutaneous site was maximal on day 2 postinjection, the reactions were painless, and the erythema and induration did not exceed $35 \mathrm{~mm}$ in diameter. The diameter of induration was not significantly different among the three conjugate vaccines or between the $5-\mu \mathrm{g}$ and $25-\mu \mathrm{g}$ s.c. doses, and was unrelated to the subject's preimmunization anti-PRP Ab level but positively correlated with preimmunization IgG $\mathrm{Ab}$ to DTd $(r=0.58, P<0.01)$. The one subject with systemic symptoms had had among the highest preimmunization antiDTd titers and had the most severe local inflammation, 70 $\mathrm{mm}$ induration at the subcutaneous site.

Increases in total anti-PRP Ab measured by radioassay at 2 wk postimmunization occurred in four of six, six of six, and five of six subjects after DTx-VS, Dcr-VS, and DTd-VS, respectively (Table III). There was considerable variation in the $\mathrm{Ab}$ levels before immunization, and thus the postimmunization differences among the three vaccines or between the $5-\mu \mathrm{g}$ and $25-\mu \mathrm{g}$ doses were not considered meaningful. (The

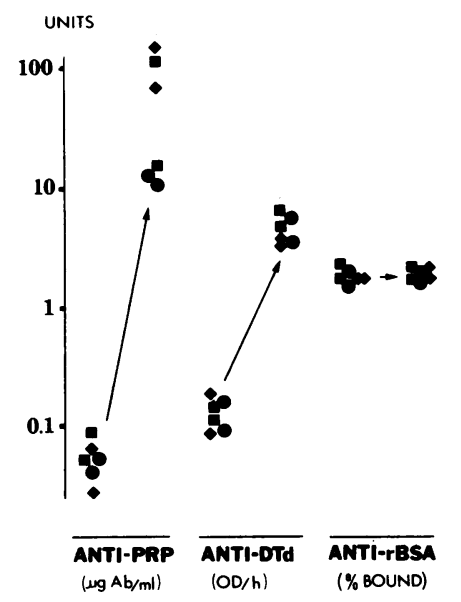

Figure 3. Effect of immunization of weanling rabbits with conjugate antigens upon several antibody assays. The numbers on the vertical axis denote the values in the respective assays in the units designated in parentheses. Anti-PRP, radioantigen binding assay for Ab to PRP (18); anti-DTd, ELISA for $A b$ to DTd; antirBSA, radioantigen binding assay for $\mathrm{Ab}$ to a $\left[{ }^{14} \mathrm{C}\right]$ ribitolylBSA conjugate. Beginning at age $6 \mathrm{wk}$, New Zealand White rabbits were injected subcutaneously three times at $1-w k$ intervals with $25 \mu \mathrm{g}$ conjugate

protein contained in $0.5 \mathrm{ml}$ of $0.0125 \mathrm{M} \mathrm{AlPO}_{4}$ suspension, pH 5.5 . The points denote serum samples before immunization and 1 wk after the third injection with DTx-VS (diamonds), Dcr-VS (circles), or DTd-VS (squares). 
Table II. Occurrence of Adverse Signs and

Symptoms After the Subcutaneous Injection of Conjugate Vaccines into Human Subjects

\begin{tabular}{|c|c|c|c|c|c|}
\hline \multirow[b]{2}{*}{$\begin{array}{l}\text { Age } \\
\text { group }\end{array}$} & \multirow[b]{2}{*}{ Vaccine } & \multirow[b]{2}{*}{ Dose } & \multicolumn{3}{|c|}{ Number of subjects with } \\
\hline & & & $\begin{array}{l}\text { No sign or } \\
\text { symptom* }\end{array}$ & $\begin{array}{l}\text { Local } \\
\text { onlył }\end{array}$ & $\begin{array}{l}\text { Local and } \\
\text { systemic§}\end{array}$ \\
\hline & & $\begin{array}{l}\mu g \\
\text { protein }\end{array}$ & & & \\
\hline \multirow[t]{6}{*}{ Adult } & DTx-VS & 5 & 1 & 2 & 0 \\
\hline & & 25 & 2 & 1 & 0 \\
\hline & Dcr-VS & 5 & 2 & 1 & 0 \\
\hline & & 25 & 1 & 2 & 0 \\
\hline & DTd-VS & 5 & 3 & 0 & 0 \\
\hline & & 25 & 1 & 1 & 1 \\
\hline \multicolumn{6}{|l|}{$19-23$} \\
\hline \multirow[t]{4}{*}{ mo } & Der-VS, primary & 25 & 7 & 1 & 0 \\
\hline & Dcr-VS, secondary & 25 & 6 & 2 & 0 \\
\hline & DTd-VS, primary & 25 & 7 & 1 & 0 \\
\hline & DTd-VS, secondary & 25 & 7 & 1 & 0 \\
\hline \multicolumn{6}{|l|}{$12-16$} \\
\hline \multirow[t]{4}{*}{ mo } & Dcr-VS, primary & 25 & 4 & 0 & 0 \\
\hline & Dcr-VS, secondary & 25 & 4 & 0 & 0 \\
\hline & DTd-VS, primary & 25 & 4 & 0 & 0 \\
\hline & DTd-VS, secondary & 25 & 4 & 0 & 0 \\
\hline
\end{tabular}

* Observed and recorded for at least $3 \mathrm{~d}$ after injection. ‡ Erythema, induration, or tenderness.

$\S$ In adults, fever, headache, malaise, myalgia, or nausea; in infants, fever or any unusual degree of irritability, sleepiness, crying, screaming, or loss of appetite.

three nonresponders had very high preimmunization $\mathrm{Ab}$ values.) The rises were similar to those in a control group vaccinated with PRP in a suboptimal dose $(1 \mu \mathrm{g})$ comparable to the PRP content in the larger dose of conjugate vaccines (Table III). In 14 of the 15 responders to conjugate vaccines, the $\mathrm{Ab}$ levels fell between 2 wk and 4 wk postimmunization (mean ratio 0.76 ), while one subject had a ratio of 1.1 (data not tabulated).

Serum BC activity against Hib increased with a frequency similar to that in radioantigen binding, and the increases in the two assays were positively correlated (for increase in micrograms of anti-PRP per milliliter vs. $\log _{2}$ of increase in BC titer, $r=0.66, P<0.01)$. The geometric mean of the ratio of postimmunization $\mathrm{BC}$ titer to micrograms of $\mathrm{Ab}$ per milliliter was 1.1 ( \pm SD $0.39-2.9)$ in comparison with 1.0 for the USFDA standard human anti-PRP serum (SK). From the six subjects in which the pre/post ratio in anti-PRP Ab was $>9$, a pool of pre- and a pool of postimmunization sera were compared in passive protection of infant rats challenged intraperitoneally with $\mathrm{Hib}$. The $50 \%$ protective titer against bacteremia was increased about eightfold by the immunization.

The IgG anti-DTd Ab increased in all subjects (Table III). The increases did not differ significantly among the three vaccines or between the two doses. Both pre- and postimmunization $\mathrm{Ab}$ were predominantly of the IgG class; IgM and IgA $\mathrm{Ab}$ were lower and increased less consistently (not tabulated). The geometric mean of all 18 subjects postimmunization was equivalent to 0.57 antitoxin-neutralizing units $(\mathrm{AU}) / \mathrm{ml}$ (where the minimal protective value is estimated as $0.01 \mathrm{AU} / \mathrm{ml}$ ). For comparison, the values of a control group of 10 subjects vaccinated with conventional Td vaccine increased to a geometric mean of $0.51 \mathrm{AU} / \mathrm{ml}$. Separately for the three conjugates, pools were made of the six pre- and the six 2-wk postimmunization sera, and these were assayed for in vitro neutralization of DTx in the rabbit skin assay. In each group the neutralizing $\mathrm{Ab}$ value increased approximately fivefold. There was no correlation between the anti-PRP and anti-DTd Ab responses to the conjugates, whether analyzed by relative or absolute increases.

Studies in infants 19-23 mo of age. Groups of eight were given a sequence of two $25-\mu \mathrm{g}$ s.c. injections of Dcr-VS or DTd-VS spaced 1 mo apart. No subject had any systemic

Table III. Serum Antibodies to PRP or to DTd in Human Adults Injected with Conjugate or Control Vaccines

\begin{tabular}{|c|c|c|c|c|c|c|c|c|}
\hline \multirow[t]{3}{*}{ Vaccine } & \multicolumn{2}{|c|}{ Amount in dose } & \multicolumn{3}{|c|}{ Antibodies to PRP } & \multicolumn{3}{|c|}{ IgG antibodies to DTd } \\
\hline & \multirow[b]{2}{*}{ Protein } & \multirow[b]{2}{*}{ PRP } & \multirow[b]{2}{*}{$\begin{array}{l}\text { Number }+ \\
\text { per total* }\end{array}$} & \multicolumn{2}{|c|}{ Geometric means } & \multirow[b]{2}{*}{$\begin{array}{l}\text { Number }+ \\
\text { per total* }\end{array}$} & \multicolumn{2}{|c|}{ Geometric means } \\
\hline & & & & $\begin{array}{l}\text { Pre- } \\
\text { immunization }\end{array}$ & $\begin{array}{l}2 \text { wk post- } \\
\text { immunization }\end{array}$ & & $\begin{array}{l}\text { Pre- } \\
\text { immunization }\end{array}$ & $\begin{array}{l}2 \text { wk post- } \\
\text { immunization }\end{array}$ \\
\hline & $\mu g$ & $\mu g$ & & $\mu g / m l$ & $\mu g / m l$ & & $A U / m l$ & $A U / m l$ \\
\hline DTx-VS & 5 & 0.22 & $3: 3$ & 2.0 & $11 \quad(4.5-29) \ddagger$ & $3: 3$ & 0.18 & $0.94(0.89-1.0) \ddagger$ \\
\hline DTx-VS & 25 & 1.1 & $1: 3$ & 16 & $18 \quad(2.8-110)$ & $3: 3$ & 0.17 & $0.50(0.13-1.8)$ \\
\hline Der-VS & 5 & 0.15 & $3: 3$ & 0.71 & $12 \quad(8.4-17)$ & $3: 3$ & 0.42 & $0.87(0.63-1.2)$ \\
\hline Dcr-VS & 25 & 0.75 & $3: 3$ & 7.4 & $27 \quad(7.3-97)$ & $3: 3$ & 0.14 & $0.31(0.20-0.48)$ \\
\hline DTd-VS & 5 & 0.29 & $3: 3$ & 1.4 & $3.0(2.6-3.6)$ & $3: 3$ & 0.13 & $0.35(0.16-0.78)$ \\
\hline DTd-VS & 25 & 1.5 & $2: 3$ & 29 & $74 \quad(20-270)$ & $3: 3$ & 0.20 & $0.80(0.37-1.7)$ \\
\hline PRP & - & 1 & $10: 10$ & 0.47 & $8.3(4.1-17)$ & - & - & - \\
\hline $\mathrm{Td} \S$ & $\S$ & - & - & - & - & $10: 10$ & 0.062 & $0.51(0.16-1.7)$ \\
\hline
\end{tabular}

* Number of subjects with a statistically significant rise per number immunized. $\ddagger \pm 1 \mathrm{SD} . \S$ Contained two flocculation units of DTd, which is equivalent to $5 \mu \mathrm{g}$ of purified DTd. 
reaction. Mild local inflammation developed after one of eight primary and two of eight secondary injections of Dcr-VS and after one of eight primary and one of eight secondary injections of DTd-VS (Table II). Thus, for the conjugates overall the rate of local reactions was 5 of 32 in the infants as compared with 8 of 18 in the adults (combining the $5-\mu \mathrm{g}$ and $25-\mu \mathrm{g}$ doses) $\left(\chi^{2}=5.0, P=0.025\right)$.

Increases in total anti-PRP Ab measured at 1 mo after the primary were found in 8 of 8 subjects after Dcr-VS, 8 of 8 after DTd-VS, and in 13 of 16 after immunization with $25 \mu \mathrm{g}$ of PRP (an optimal dose). At 1 mo after the secondary injection of PRP only 3 of the 16 infants had increases, and the geometric mean (Fig. 4) did not rise. In contrast, after either of the conjugates there were postsecondary increases in eight of eight infants. The geometric mean after DTd-VS (3.1 $\mu \mathrm{g} / \mathrm{ml})$ significantly exceeded that after PRP $(0.50 \mu \mathrm{g} / \mathrm{ml})$, and that after Dcr-VS $(15 \mu \mathrm{g} / \mathrm{ml})$ exceeded both the others. By 5 mo after the secondary the means of all three groups had declined; the falloff after Dcr-VS was faster, such that Dcr-VS and DTd-VS no longer differed significantly but both exceeded PRP (Fig. 4).

Before immunization none of the infants had detectable BC activity ( $<50 \%$ killing at 1:2 dilution), and the anti-PRP $\mathrm{Ab}$ as detected in an Ig class-specific ELISA was largely IgM (Fig. 5). After the primary injection with any of the vaccines small increases in BC activity were found in just under half the subjects, and rises in the class-specific ELISA were mainly in IgM with a few small rises in IgG and IgA (not shown). At 1 mo after the secondary, BC activity was found in 6 of 16 infants after PRP, in 6 of 8 after DTd-VS, and in 8 of 8 after Dcr-VS; the mean $\log _{2}$ for $50 \%$ killing increased to $0.3,0.8$, and 3.1, respectively (Fig. 5). For DTd-VS and Dcr-VS combined, the geometric mean ratio of $\mathrm{BC}$ titer to micrograms of anti-PRP Ab per milliliter was 0.64 ( \pm SD $0.27-1.5$ ). There was little change in Ig class distribution after the secondary

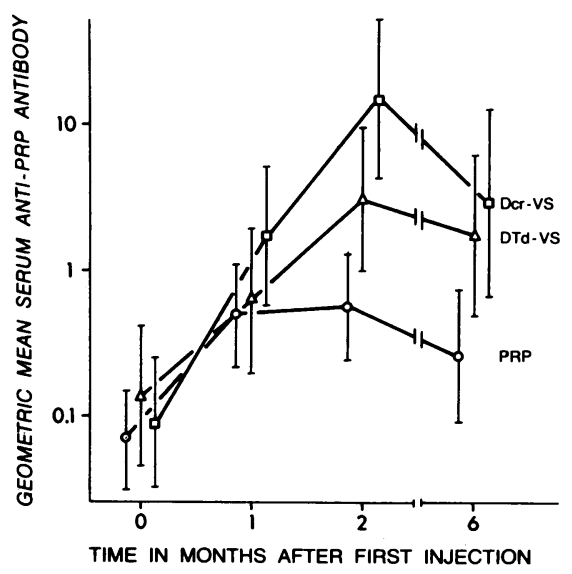

Figure 4. Serum Ab to PRP in infants immunized with PRP or the conjugate vaccines Dcr-VS or DTd-VS beginning at age 19-23 mo. Groups of 8 subjects were injected subcutaneously with $25 \mu \mathrm{g}$ of conjugate vaccine and a group of 16 subjects with $25 \mu \mathrm{g}$ of PRP vaccine just after the serum sample at 0 mo and again after sample at $1 \mathrm{mo}$. Ab concentrations were estimated by radioantigen binding. The vertical bars show a $95 \%$ confidence interval for the geometric means.

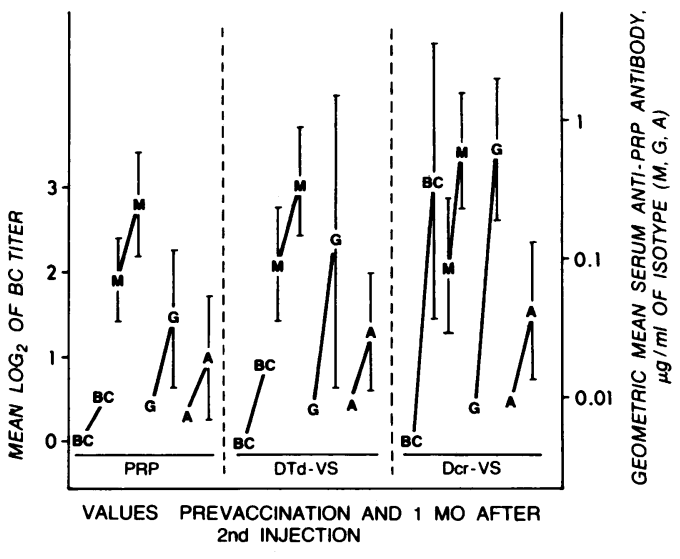

Figure 5. Serum BC activity against Hib and immunoglobulin class (isotype)-specific antibodies to PRP in infants immunized with PRP or the conjugate vaccines Dcr-VS or DTd-VS beginning at age 19-23 mo. The subjects and immunizations were the same as in Fig. 4. BC titers of two were called one $\left(\log _{2}=0\right)$ for calculating the mean, and values below the detectable limits in the isotype-specific immunosorbent assays were assigned half those values. The vertical bars show 95\% confidence intervals, but no intervals were calculated for means that included a majority of values below detectable limits.

vaccination with PRP. After DTd-VS there was a large relative increase in IgG, although IgM remained the predominant class. After Dcr-VS the IgG Ab rose strongly and equaled the IgM component (Fig. 5).

Generally the subjects had high levels of Ab to DTd before immunization. All had rises after both the primary and secondary injections. The geometric means preimmunization and 1 mo postsecondary were 0.75 and $3.1 \mathrm{AU} / \mathrm{ml}$, respectively, with Dcr-VS, and 0.64 and $3.9 \mathrm{AU} / \mathrm{ml}$ with DTd-VS.

Studies in infants 12-16 mo of age. Groups of four each were given Dcr-VS or DTd-VS in the same schedule as in the older infants. There were no observed local or systemic adverse reactions (Table II). Increases in total anti-PRP Ab (Table IV) measured $1 \mathrm{mo}$ after the primary were found in four of four after Dcr-VS, two of four after DTd-VS, and three of eight in the (noncohort) control group that received PRP; the levels in the Dcr-VS group were significantly higher than in the other two groups by the rank sum test $(P<0.05)$. At 1 mo after the secondary there were no further increases in the PRP group, small additional rises in the two primary responders in the DTd-VS group, and large increases in four of the four in the Dcr-VS group, which had a geometric mean $(4.4 \mu \mathrm{g} / \mathrm{ml}) \sim 50$ fold higher than the other two $(P<0.05$ by rank sum test or $t$ test). In the Dcr-VS group there was an IgG component in all four anti-PRP responses and BC activity in three of the four; the geometric mean ratio of $\mathrm{BC}$ titer to micrograms of anti-PRP Ab was 0.59 ( \pm SD 0.34-1.0). IgG $A b$ and $B C$ activity were not detected in the other two groups (not shown). By 5 mo after the secondary the levels had declined in all, but the Dcr-VS group nonetheless had a mean $(1.3 \mu \mathrm{g} / \mathrm{ml}) \sim 20$-fold higher than the other groups $(P<0.05)$ (Table IV). There were rises in IgG $A b$ to DTd after both primary and secondary immunizations with both conjugates; the geometric means 1 mo postsecondary were $\sim 3 \mathrm{AU} / \mathrm{ml}$ after each. 
Table IV. Serum Ab to PRP in Infants Immunized* with Conjugate or PRP Vaccines Beginning at Age 12-16 Mo

\begin{tabular}{|c|c|c|c|c|c|}
\hline \multirow[b]{2}{*}{ Vaccine } & \multirow[b]{2}{*}{$\begin{array}{l}\text { Number per } \\
\text { total§ }\end{array}$} & \multicolumn{4}{|c|}{ Geometric mean $\ddagger$ of anti-PRP Ab levels at } \\
\hline & & Preimmunization & $\begin{array}{l}1 \text { mo post- } \\
\text { immunization }\end{array}$ & $\begin{array}{l}2 \text { mo ( } \pm \text { SD) } \\
\text { postimmunization }\end{array}$ & $\begin{array}{l}6 \text { mo }( \pm S D) \\
\text { postimmunization }\end{array}$ \\
\hline & & $\mu g$ & $\mu g$ & $\mu g$ & $\mu g$ \\
\hline Dcr-VS & $4: 4$ & 0.054 & $0.38^{\prime \prime}$ & $4.4 \pi \quad(0.57-34)$ & $1.3 \pi \quad(0.29-4.5)$ \\
\hline DTd-VS & $2: 4$ & 0.019 & 0.020 & $0.078(0.008-0.81)$ & $0.062(0.005-0.76)$ \\
\hline PRP & $3: 8$ & 0.040 & 0.064 & $0.073(0.006-0.90)$ & $0.050(0.004-0.61)$ \\
\hline
\end{tabular}

* Subjects received $25 \mu \mathrm{g}$ s.c. of the indicated vaccine just after serum sample "Preimmunization" and again just after sample "1 mo postimmunization." ‡ Values below the detectable level of $0.025 \mu \mathrm{g} / \mathrm{ml}$ were assigned half this value for the calculation. $\S$ Number of subjects with a statistically significant rise between the preimmunization and 1-mo or 2-mo postimmunization serum samples per number immunized. "Differs from both groups below by rank sum test, $P<0.05$. I Differs from both groups below by rank sum test and by $t$ test, $P<0.05$.

\section{Discussion}

Goebel's principle of using saccharide haptens to induce antimicrobial immunity has frequently been used to analyze the specificity of host resistance (21), but only recently for human vaccination. Mature humans, unlike many experimental mammals, make good $\mathrm{Ab}$ responses to the purified capsular polysaccharides of many invasive bacterial species (22). However, immunocompetence to these polymers matures more slowly than to proteins and lipopolysaccharides. It has been hypothesized that conjugation of capsular antigens to protein carriers might circumvent the delay in maturation and thus immunize infants, who are generally at higher risk than adults (23). Protein-coupled capsular antigens have been described as potential immunogens against Neisseria meningitidis $(24,25)$ and Streptococcus pneumoniae $(3,26)$ as well as Hib $(3,27$, 28 , and enhanced $\mathrm{Ab}$ responses have been found in experimental animals. Because of species differences in antisaccharide responses (10) and because the maturation of immunocompetence in laboratory animal species proceeds on a schedule different from humans (29), the optimal properties of such immunogens may need to be defined in immunogenicity studies in human infants. The methodology described in reference 27 has been used to make protein-coupled (polymeric) PRP that has an increased immunogenicity in human adults (28) and infants $(30,31)$.

Our approach to coupled capsular immunogens included depolymerizing the PRP and using a simple coupling chemistry. Highly polymerized identical epitopes are believed to account for the $\mathrm{T}$ lymphocyte-independent character of polysaccharide antigens (23), thus the presentation of oligosaccharides on the carrier protein might make the conjugate more subject to $T$ lymphocyte helper effects. Empirically, it was recently found that protein conjugates made with low molecular weight dextrans gave higher secondary responses in mice than conjugates made with macromolecular dextran (32). Our coupling was done without linker compounds, whose pharmacologic properties are difficult to evaluate, and employed reductive amination, which forms a simple amino linkage (12) unlike the linkages present in natural glycoproteins (33). It may be important that the conjugation reaction not create neoantigenic determinants (34) cross-reactive with human antigens, since such a determinant borne on a potent carrier might in a neonate induce an anti-self response with a pathologic potential.
Our conjugates, when injected with $\mathrm{AlPO}_{4}$ three times into weanling rabbits, raised copious Ab to PRP and to DTd but no detectable $\mathrm{Ab}$ to a model ligand of the linkage. Thus the linkage appears weakly immunogenic if at all.

As a potential carrier, DTd has a record of safe human usage and is readily available; we also examined DTx and Dcr, in which more amino groups are accessible for coupling but which have the drawbacks of potential toxicity and limited supply, respectively (4). Experience with tetanus toxin (35) suggested that the coupling reaction would reduce the toxicity of DTx, as was found. Formalinization of the conjugates after coupling (done for stabilization of the diphtheria component [5]) also reduced the residual $1 \%$ toxicity of DTx-VS by $>100$ fold. However, there was a slight retoxification upon storage at $4^{\circ} \mathrm{C}$ and a faster one at $37^{\circ} \mathrm{C}$. Reversibility of the detoxification of purified DTx by formaldehyde is commonly observed (8). Thus, in the absence of compelling advantages of beginning with native toxin, making conjugates with the inherently nontoxic Dcr or stably detoxified DTd are preferable.

8 of the 18 immunized adults had delayed local inflammation, the degree of which was correlated with preimmunization IgG Ab to the diphtheria component. Potentially, the $\mathrm{Ab}$ could be a mediator of the reaction (Arthus) or merely an indicator of sensitization (with the reaction being cell-mediated). Since hypersensitivity is common after reimmunization of adults with diphtheria and tetanus toxoids (36), reactions after the conjugates were expected. Hypersensitivity reactions to toxoids is less of a problem in infants, and the same appeared to be true of these conjugates.

The adults consistently made an anti-PRP Ab response to the conjugates, and these $\mathrm{Ab}$ were similar to those raised by PRP in protective potential. Secondary injections to examine for secondary responses were not done due to the potential for hypersensitivity.

Infants 18-23 mo of age were appropriate for a controlled comparison because the response to PRP vaccine was immature but readily measurable and marginally protective, thus either a superior or an inferior immunogenicity of the conjugates could be detected. The telling results were the responses to secondary immunizations and the Ig class distributions. As in previous studies (17), the second injection of PRP generally failed to boost the $\mathrm{Ab}$ level, while with both tested conjugates there were exponentially increased levels 1 mo after the secondary. Multiple sera were not obtained before the secondary 
to establish that the primary response had plateaued; however, since the adult $\mathrm{Ab}$ levels at 2 wk exceeded those at 4 wk postimmunization, the rises in infants after the secondary probably represents an anamnestic response rather than a continued response to the primary. As expected (1), the response to PRP in most of the infants was restricted to the IgM class, with but a few rises also in IgG. In contrast, the secondary responses to the conjugates showed an increased participation of $\mathrm{IgG}$, characteristic of more mature responses to PRP (1).

It is now known that immunization with PRP below 18 mo of age is unlikely to be protective (1). Thus in the 12-16 mo age range, data previously obtained (17) were used as a control rather than a PRP-vaccinated cohort. DTd-VS was only weakly immunogenic, while Dcr-VS showed an increased primary and a sharply enhanced secondary response with an IgG component. The total $\mathrm{Ab}$ after Dcr-VS also was high in relation to levels estimated to be protective (37). The ratios of $\mathrm{BC}$ titer to anti-PRP Ab level further indicate that the $\mathrm{Ab}$ induced in infants by the conjugated oligosaccharide have a protective potential against encapsulated Hib.

Conjugate Dcr-VS elicited significantly higher $\mathrm{Ab}$ levels in both groups of infants than DTd-VS. The 5-mo falloff after Dcr-VS was also faster. The basis is uncertain, but we speculate that both observations might result from the aggregated state of Dcr-VS, which could enhance both immunologic processing as well as elimination of the antigen.

It might eventually be useful to substitute a conjugate for ordinary DTd in routine immunization. Thus it was welcome that the immunized subjects had a rise in Ab to DTd and (in the tested adults) a rise in DTx neutralizing activity.

\section{Acknowledgments}

The authors are grateful to Joyce Colaiace and Susan Porcelli for technical assistance, K. R. Powell, D. H. Smith, R. Schneerson, and J. B. Robbins for valuable discussion, and the human subjects who volunteered for the study without compensation.

This work was supported by U. S. Public Health Service grants AI 17938 and $\mathrm{AI} 12673$.

\section{References}

1. Peltola, H., H. Kayhty, A. Sivonen, and P. H. Makela. 1977. Haemophilus influenzae type $\mathrm{b}$ capsular polysaccharide vaccine in children: a double-blind field study of 100,000 vaccines 3 months to 5 years of age in Finland. Pediatrics. 60:730-737.

2. Goebel, W. F. 1939. The immunological properties of an artificial antigen containing cellobiuronic acid. J. Exp. Med. 68:469481.

3. Chu, C., R. Scheerson, J. B. Robbins, and S. Rastogi. 1983. Further studies on the immunogenicity of Haemophilus influenzae type $\mathrm{b}$ and pneumococcal type $6 \mathrm{~A}$ polysaccharide protein conjugates. Infect. Immun. 40:245-256.

4. Anderson, P. 1983. Antibody responses to Haemophilus influenzae type $b$ and diphtheria toxin induced by conjugates of oligosaccharides of the type b capsule with the nontoxic protein CRM197. Infect. Immun. 39:233-238.

5. Pappenheimer, A. M., Jr., T. Uchida, and A. A. Harper. 1972. An immunological study of the diphtheria toxin molecule. Immunochemistry. 9:891-906.

6. Lowry, O. H., N. J. Rosebrough, A. L. Farr, and R. J. Randall.
1951. Protein measurement with the Folin phenol reagent. J. Biol. Chem. 193:265-275.

7. Laemmli, U. K. 1970. Cleavage of structural proteins during the assembly of the head of bacteriophage T4. Nature (Lond.). 227:680685.

8. Linggood, F. V., M. F. Stevens, A. J. Fulthorpe, A. J. Worwood, and C. G. Pope. 1963. The toxoiding of purified diphtheria toxin. $B r$. J. Exp. Pathol. 44(2):177-188.

9. Anderson, P., and D. H. Smith. 1977. Isolation of the capsular polysaccharide from culture supernatant of Haemophilus influenzae type b. Infect. Immun. 15:472-477.

10. Kabat, E. A., and M. M. Mayer. 1961. Experimental Immunochemistry. C. C. Thomas, Springfield, IL. Second ed. 501-530.

11. Chen, P. S., T. Y. Toribara, and H. Warner. 1956. Microdetermination of phosphorus. Anal. Chem. 28:1756-1758.

12. Schwartz, B. A., and G. R. Gray. 1977. Proteins containing reductively aminated disaccharides. Arch. Biochem. Biophys. 181:542549.

13. Office of the Federal Register. 1981. Code of Federal Regulations. Revision part 610. U.S. Government Printing Office, Washington, DC.

14. Rojas-Corona, R. R., R. Skarnes, S. Tarmakuma, and J. Fine. 1969. The limulus coagulation test for endotoxin. A comparison with other assay methods. Proc. Soc. Exp. Biol. Med. 132:599-601.

15. Flesher, A. R., and R. A. Insel. 1978. Characterization of lipopolysaccharide of Haemophilus influenzae. J. Infect. Dis. 138:719730 .

16. Fraser, D. T. 1931. The technique of a method for the quantitative determination of diphtheria antitoxin by a skin test in rabbits. Trans. $R$. Soc. Can. 25:175-181.

17. Anderson, P., D. H. Smith, D. L. Ingram, J. Wilkins, P. F. Wehrle, and V. Howie. 1977. Antibody to polyribophosphate of Haemophilus influenzae type b in infants and children: effect of immunization with polyribophosphate. J. Infect. Dis. 136:S57-S62.

18. Anderson, P. 1978. Intrinsic tritium labeling of the capsular polysaccharide antigen of Haemophilus influenzae type b. J. Immunol. 120:866-870.

19. Anderson, P., A. Flesher, S. Shaw, A. L. Harding, and D. H. Smith. 1980. Phenotypic and genetic variation in the susceptibility of $H$. influenzae type b to antibodies to somatic antigens. J. Clin. Invest. 65:885-891.

20. Colton, T. 1974. Statistics in Medicine. Little, Brown \& Co. Boston. 372 pp.

21. Jann, K., and O. Westphal. 1975. Microbial polysaccharides. In The Antigens, Vol. 3. M. Sela, editor. Academic Press, New York, $126 \mathrm{pp}$.

22. Robbins, J. B. 1978. Vaccines for the prevention of encapsulated bacterial diseases. Current status, problems and prospects for the future. Immunochemistry. 15:839-854.

23. Paul, W. E. 1973. New Approaches for Inducing Natural Immunity to Pyrogenic Organisms. Department of Health, Education and Welfare Publication No. (National Institutes of Health) 74-553. U. S. Government Printing Office, Washington, DC. 157-166.

24. Jennings, H. J., and C. Lugowski. 1981. Immunochemistry of groups $\mathrm{A}, \mathrm{B}$, and $\mathrm{C}$ meningococcal polysaccharide-tetanus toxoid conjugates. J. Immunol. 127:1011-1018.

25. Beuvery, E. C., F. Miedema, R. vanDelft, and J. Haverkamp. 1983. Preparation and immunochemical characterization of meningococcal group $C$ polysaccharide-tetanus toxoid conjugates as a new generation of vaccines. Infect. Immun. 40:39-45.

26. Lin, K. T., and C. J. Lee. 1982. Immune response of neonates to pneumococcal polysaccharide-protein conjugate. Immunology. 46: 333-342.

27. Schneerson, R., O. Barrera, A. Sutton, and J. Robbins. 1980. Preparation, characterization, and immunogenicity of Haemophilus influenzae type b polysaccharide-protein conjugates. J. Exp. Med. 152: 361-376. 
28. Granoff, D. M., E. G. Boies, and R. S. Munson, Jr. 1984. Immunogenicity of Haemophilus influenzae type b polysaccharidediphtheria toxoid conjugate vaccine in adults. J. Pediatr. 105:22-27.

29. Solomon, J. B. 1971. Fetal and Neonatal Immunology. North Holland Publishing Co., Amsterdam.

30. Ward, J., C. Berkowitz, J. Pescetti, K. Burkart, J. Samuelson, and L. Gordon. 1984. Enhanced immunogenicity in young infants of a new Haemophilus influenzae type b (Hib) capsular polysaccharide (PRP)-diphtheria toxoid (D) conjugate vaccine. Pediatr. Res. 18:287a. (Abstr.)

31. Zahradnik, J. M., and L. K. Gordon. 1984. Augmented antibody (Ab) responses in infants administered a new Haemophilus influenzae type $\mathrm{b}$ capsular polysaccharide (PRP) diphtheria toxoid conjugate vaccine (PRP-D). Pediatr. Res. 18:289a. (Abstr.)

32. Makela, O., F. Peterfy, I. G. Outschoorn, A. W. Richter, and
I. Seppala. 1984. Immunogenic properties of a (1-6) dextran, its protein conjugates and conjugates of its breakdown products in mice. Scand. J. Immunol. 19:541-550.

33. Aplin, J. D., and J. C. Wriston, Jr. 1981. Preparation, properties, and applications of carbohydrate conjugates of proteins and lipids. Crit. Rev. Biochem. 1981:259-306.

34. Naor, D., and N. Galili. 1977. Immune response to chemically modified antigens. Prog. Allergy. 22:107-146.

35. Matuhasi, T., A. Yamamoto, S. Sadahiro, and H. Ikegami. 1981. A new approach to make toxoid eliciting good IgM and/or IgG but little IgE antibody responses. Naturwissenschaften. 68:549.

36. Middaugh, J. P. 1979. Side effects of diphtheria-tetanus toxoid in adults. Am. J. Public Health. 69:246-249.

37. Anderson, P. 1984. The protective level of serum antibodies to the capsular polysaccharide of Haemophilus influenzae type b. J. Infect. Dis. 149:1034. 